\title{
Post Mining Evaluation of Forest Land Rehabilitation and Potential Ecosystem Recovery
}

\author{
Triyono Sudarmadji ${ }^{1, *}$ Wahjuni Hartati ${ }^{2}$
}

\author{
${ }^{1}$ Laboratory of Soil-Water Conservation and Climate, Faculty of Forestry, University of Mulawarman. Samarinda, \\ East Kalimantan, Indonesia. \\ ${ }^{2}$ Laboratory of Soil and Forest Nutrition, Faculty of Forestry, University of Mulawarman. Samarinda, East \\ Kalimantan, Indonesia \\ *Corresponding author.Email: triyonosudarmadji@gmail.com
}

\begin{abstract}
Coal Mining operation in the forest lands caused significant forest ecosystem disturbance. Therefore, management of mined-out forest lands must be conducted thoroughly following land clearing, topsoils spreading, mining waste treatment, land rehabilitation (reclamation and Revegetation). Concerning expected ecosystem recovery, mined-out forest lands rehabilitation must be carried out covering land arrangement, soil erosion-sedimentation control, and land revegetation. These three aspects were evaluated to assess whether successful or not based on the performance of land reclamation, soil erosion-sedimentation land revegetation (planted areas, growth percentage, plant species, the composition of fast-growing and long-lived species, plant health). This study was conducted at PT Santan Batubara mining concession of 507.3 ha in large with 469.14 ha has been cleared and 24.47 ha already rehabilitated with a fast growing and long life plants species. Rehabilitation score were 81.83 (OPD-Komodo 2010: 5.39 ha); 88.0 (IPDaKomodo 2010: 5.11 ha); 87,3 (KO-Komodo 2010: 2.24 ha); 89.3 (OPDb-M2 2011: 1,72 ha); 85.8 (OPDa-M2 2010: $8.54 \mathrm{ha}$ ); 84.7 (OPDc-M2 2011: $0.37 \mathrm{ha}$ ); 85.2 (OPDd-M2 2011: $1.10 \mathrm{ha}$ ) respectively, with the total score 602.1 and 86.0 in average. The score of ecosystem related to foodweb recovery based on incoming herbivores - predators carnivores without top carnivores was found to be 70, classified as the prospective status of ecosystem recovery. The prospective status indicates that the processes of forest ecosystem recovery have been in the expected direction.
\end{abstract}

Keywords: Soil Erosion-Sedimentation, Ecosystem Recovery, Land Reclamation, Forest Rehabilitation, Land Revegetation

\section{INTRODUCTION}

Coal Mining operation in the forest land causes significant forest ecosystem disturbances. Therefore, forest ecosystem management must be conducted thoroughly following land clearing, topsoils spreading, mining waste treatment, land rehabilitation (reclamation and Revegetation), and all things related to pre-mining post-coal mining activities [1, 2, 3, 4]. The utilization of non-renewable natural resources should be rational, efficient and not wasteful [2]. Post mining land remains as degraded material layers cover the aggregate crushed, broken porous soil structure, rock fragments mixed coal, and disappear layer of organic material. Besides that, terrible drainage, incapable soil water holding water capacity, and high soil density and temperature $(25,30)$.
Open-pit/cast mining system applied by PT Santan Batubara consist of land clearing - blasting - stripping mining - backfilling - topsoils spreading - planting works. This mining operation method is expected to minimize the open area resulting from coal mining operation using various heavy equipment. Coal mining covers land clearing, blasting, topsoils stripping, extracting overburden materials, mining operation, hauling and crushing, and loading coal onto coal transporters. The direct impact is the structure and function of ecosystems damage due to coal mining operation [1]. PT Santan Batubara concerns the mandatory obligation and is responsible for rehabilitating minedout forest land to restore forest ecosystems' structure and function. 
Concerning the ecosystem restoration, the Ministry of Forestry Government of Indonesia (FoF-GoI) declares Permenhut P.76/2008 about forest reclamation and rehabilitation to convene forest functions, authorities and responsibilities, local authorities and concession holders to organize degraded land rehabilitation work in planning, implementation, monitoring and evaluation $[15,16]$. Furthermore, the technical instructions of forest reclamation activities are then elaborated in P.4/Menhut-II/2011 about forest reclamation guidelines and technical education related to stakeholders and assessment procedure as mandated by Permenhut P.60/Menhut-II/2009 on the guidelines for the assessment of the forest reclamation [17, 18, 19].

Post-mining forest land area is not ready to be a medium for supporting plant growth. Therefore forest rehabilitation efforts must be carried out on land arrangement, erosion-sedimentation control, and land revegetation, especially in the post-mining forest land areas. Monitoring and evaluation are conducted over these three degraded land rehabilitation aspects to understand and formulate best ecosystem recovery practices [08, 20, 24].

This study's main objective was to evaluate the progress of land rehabilitation works carried out at postmining forests lands in complying with its obligation and achievement properly. The expected result and benefits were to understand degraded land rehabilitation successfulness of it's rehabilitated forest lands, which will also be used to improve and develop an instrument of decision making policy related to the actual condition of mined-out forest lands.

\section{METHOD}

\subsection{Study Area}

The mining concession under status IPPKH - Ijin Pinjam Pakai Kawasan Hutan (Utilization Forest Permit) of PT Santan Batubara was 16.700 ha in large located in Kutai Kartanegara Regency, 8.172 ha in East Kutai Regency, and 58 ha in Bontang City. Evaluation of mined-out forest land rehabilitation and its potential ecosystem recovery was carried out based on land arrangement criteria, soil erosion-sedimentation control measure, land revegetation, and ecosystem recovery status [16]. This study was conducted at nearly 25 ha of OPD-Komodo site (5.39 ha), IPDa-Komodo site (5.11 ha), KO-Komodo site (2.24 ha), OPDb-M2 site (1.72 ha), OPDa-M2 site ( 8.54 ha), OPDc-M2 site (0.37 ha), as well as OPDd-M2 site (1.20 ha) respectively (Figure $1)$.

\subsection{Study Procedure}

The study procedures to evaluate rehabilitation works carried out at post-mining forest lands are as follows:

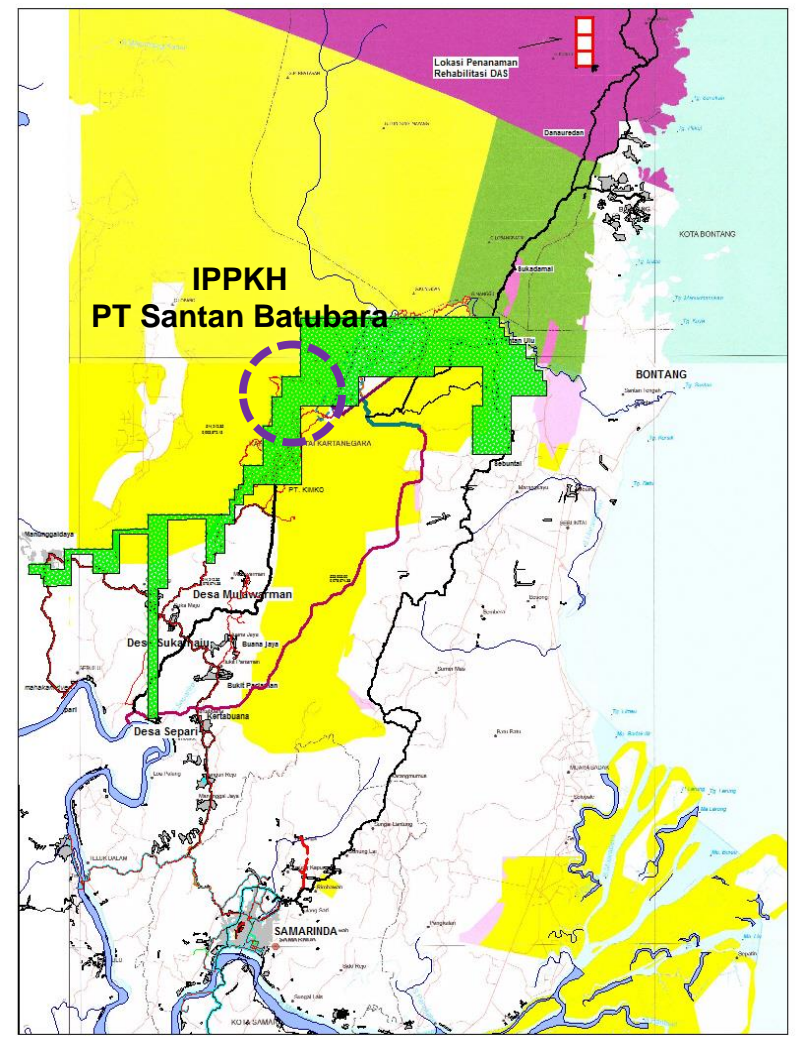

Figure 1 The study area of PT Santan Batubara concession

\subsubsection{Land Arrangement}

Land arrangement's primary parameter is void backfilling, land preparation, slope stability, and topsoils spreading. Scoring of backfilling and the land arrangement was applied by comparing work progress to the plan set up in technical mining and environmental planning. Observation of slope stability was done directly in the field related to landslide movements. At the same time, soil depth after topsoils spreading was measured purposively in the area by using a soil hand auger.

\subsubsection{Soil erosion and sedimentation}

The field installation of soil and water conservation infrastructures such as check dam, drop structures, and drainage channels were observed whether working correctly or not with its function and benefits. Legume cover crops (Lcc) intended to retard excessive overland flow and increase infiltration capacity were done by assessing Lcc growth after land preparation. Soil 
erosion and sedimentation were observed by identifying soil erosion types and it's distribution.

\subsubsection{Revegetation}

The revegetated mined-out area was observed within rehabilitated forest lands by census method to collect data of growth percentage and plant species composition between fast-growing and long life plant species and plant health.

\section{DATA ANALYSIS}

Based on the applied study method, each land rehabilitation evaluation parameter was classified in a five-level score ranging from highest rank (5) to the lowest rank (1) following the degree level of successfulness.

\subsection{Land Arrangement (weighted $=30$ )}

The land arrangement work was scored by comparing work progress achieved with it's planning previously set up as if the progress $>90 \%$ (5), 80-90\% (4), $70-79 \%$ (3), 60-69\% (2), and if the progress $<60 \%$ (1). Scoring for land preparation was based on a comparison of progress achieved with prior land preparation planning. As if the progress $>90 \%$ (5), 80$90 \%$ (4), $70-79 \%$ (3), 60-69\% (2), and if the progress $<60 \%$ (1). Further, scoring for slope stability was very slight $<5 \%$ (5), slight 5-10\% (4), moderate $11-15 \%$ (3), heavy $16-20 \%$ (2), and very heavy $>20 \%$ (1). Moreover, for the legume cover crops was scored as if the progress $>90 \%$ (5), $80-90 \%$ (4), 70-79\% (3), 60-69\% (2), as well as for the progress $<60 \%$ (1).

\subsection{Soil Erosion-Sedimentation and Landslide Countermeasure (weighted $=20$ )}

Assessment of soil conservation infrastructure was based on the percentage of the installed unit number divided by the total number described in the technical mining and environmental planning. The assessment was done as if $>90 \%$ (5), $80-90 \%$ (4), $70-79 \%$ (3), 60$69 \%$ (2), and if $<60 \%$ (1). Soil conservation infrastructure function was also assessed whether contributing to the soil erosion control and sedimentation or not. The benefit assessment was instrumental (5), useful (4), slightly useful (3), less useful (2) and when it was not useful (1). As general guidance, some function and benefits of soil conservation infrastructure are: retaining dam can control overland flow coming from upstream catchment as well as increasing surface groundwater in the downstream; check dam can control overland flow coming from upstream catchment areas, raising the surface water of the surrounding land, and the site of a water supply for surrounding communities; drop structure retards overland flow; water channel is capable of storing channelling overland flow; as well as valley construction control can prevent the gully erosion occurrences.

For cover crops planting, the assessment was based on five categories, namely when the Lcc planting work $>90 \%$ (5), 80-90\% (4), 70-79\% (3), 60-69\% (2), as well as if planting work $<60 \%$ (1). Subsequently, soil erosion and sedimentation control assessment were also classified into five categories if very light erosion $<5 \%$ (5), light 6-10\% (4), moderate (11-15\%), (3), and heavy $16-20 \%(2)$, as well as if soil erosion was very heavy $>20 \%$ (1).

\subsection{Land Revegetation (weighted $=50$ )}

For the assessment of land revegetation ( $>4$ years old), if the revegetation works $>90 \%$ (5), 80-90\% (4), $70-79 \%$ (3), $60-69 \%$ (2), as well as if revegetation works $<60 \%$ (1). The plant growth percentage score was based on comparing the number of existing plants with the number that are supposed to be in the rehabilitated areas. The score of growth percentage is as if $>90 \%$ (5), $80-90 \%$ (4), $70-79 \%$ (3), $60-69 \%$ (2), as well as if $<60 \%$ (1). The number of plants per hectare set at a planting distance of $4 \mathrm{~m} \times 4 \mathrm{~m}$ so that the minimum number of trees per hectare is 625 trees. The score areas if $>625$ trees/ha (5), 611-612 trees/ha (4), 476-550 trees/ha (3), 400-475 trees/ha (2) and <400 trees/ha (1).

In general, land rehabilitation works always begins with the fast-growing species planting and enriched further with long life local species. The diversity of plant species depends on the function and designation of rehabilitated areas. Considering the given status of production forest, the minimum number of long-life plant species is at least $40 \%$ of whole plants and expected having multi-purpose tree species (MPTS) in the revegetated areas. The score is classified as if $>40 \%$ (5), 30-39\% (4), $20-29 \%$ (3), $10-19 \%$ (2) as well as if $<10 \%(1)$.

Plant growth is differentiated into healthy, less healthy, and not healthy. Healthy plants grow fresh and relatively straight, dense crown with standard height, free of pests and plant diseases. Plants grow healthier when well maintained as weeding, fertilizing, and eradicating pests and diseases and weeds. Less healthy plants abnormally grow or stricken with pests and diseases, yellow leaves or coloured and sometimes crooked trunk. Abnormal plant growth is stricken with pests are kept small. The score was healthy plant $>90 \%$ (5), $80-89 \%$ (4), $70-79 \%$ (3), 60-69\% (2) as well as $<60 \%$ (1).

Referring to the above description, the results of land rehabilitation assessment follow general criteria as follow: (1) if the overall outcome of rehabilitation reached a total score $\geq$ of 80 , rehabilitation works is 
declared to be successful; (2) if the total score between 60-79 expresses less successful, as well as in a total score $<60$ is not successful.

For the forest ecosystem recovery, this research used ecological indicators and status as the value of the ecosystem at different age of post-mining forest land rehabilitation [6], with a criterion of recover - if the ecological condition was similar to the prior mining operation, complete - if the ecological state showed a redeveloped food chain of the herbivore-predatorcarnivore-top predator, prospective - if the ecological condition showed a re-developed food chain but without the existence of top predator, unbalanced - if the producer condition were less than initial forest ecosystem as well as failed - if the producer were less than initial forest ecosystem without any key species [3, 12, 13] (Table 1 and Table 2).

Table 1. Ecological indicator (consumer/fauna) and ages distribution of post-mining rehabilitated forest land [3]

\begin{tabular}{|c|c|c|c|c|c|c|c|c|}
\hline \multirow{3}{*}{ No. } & \multirow{3}{*}{ Fauna Indicator } & \multicolumn{7}{|c|}{ Year age } \\
\hline & & $1-<3$ & $3-<6$ & $6-<9$ & $9-<14$ & $14-<20$ & $20-<27$ & $\geq 27$ \\
\hline & & \multicolumn{7}{|c|}{ Score/Value } \\
\hline 01. & Herbivore & 60 & 50 & 40 & 30 & 20 & 10 & 0 \\
\hline 02. & Herbivore + Predator & 70 & 60 & 50 & 40 & 30 & 20 & 10 \\
\hline 03. & Herbivore + Predator + Carnivore & 80 & 70 & 60 & 50 & 40 & 30 & 20 \\
\hline 04. & Herbivore + Predator + Carnivore + Top predator & 90 & 80 & 70 & 60 & 50 & 40 & 30 \\
\hline 05. & Herbivore + Predator + Carnivore + Top predator & 100 & 90 & 80 & 70 & 60 & 50 & 40 \\
\hline
\end{tabular}

Table 2. Status and value of ecosystem at various ages of post-mining rehabilitated forest lands [3]

\begin{tabular}{|c|c|c|c|c|c|c|c|c|}
\hline \multirow{2}{*}{ No. } & \multirow{2}{*}{ Ecosystem status } & \multicolumn{7}{|c|}{ Year age } \\
\hline & & $1-<3$ & $3-<6$ & $6-<9$ & $9-<14$ & $14-<20$ & $20-<27$ & $\geq 27$ \\
\hline 01. & Disabled/Failed/Not Yet & 60 & 50 & 40 & 30 & 20 & 10 & 0 \\
\hline 02. & Unbalance & 70 & 60 & 50 & 40 & 30 & 20 & 10 \\
\hline 03. & Prospective & 80 & 70 & 60 & 50 & 40 & 30 & 20 \\
\hline 04. & Complete & 90 & 80 & 70 & 60 & 50 & 40 & 30 \\
\hline 05. & Recovered & 100 & 90 & 80 & 70 & 60 & 50 & 40 \\
\hline
\end{tabular}

Note: Recovered = ecological condition of rehabilitation area is similar with initial baseline (QS - Community Similarity): $90-100 \%)$, Complete $=$ rehabilitation area shows the existence of a complete food web (QS: 75-90\%), Prospective = rehabilitation area indicate the existence of foodweb but without the presence of top predators (QS: 60-70\%) Unbalance = condition of consumer herbivores is less than initial conditions (QS: 50- 60\%), Failed = producer conditions is less than baseline without the presence of key species $(\mathrm{QS}<50 \%)$.

\section{RESULTS AND DISCUSSION}

\subsection{Land Arrangement}

\subsubsection{Void Backfilling}

Backfilling work was done at IPDa-Komodo with close to $>90 \%$ (Figure 2) from the plan previously set up in the area of 5.11 ha. This work is vital in achieving safe and enabling landscaping phases of mined-out forest land for complete land rehabilitation works and ecosystem recovery [14].

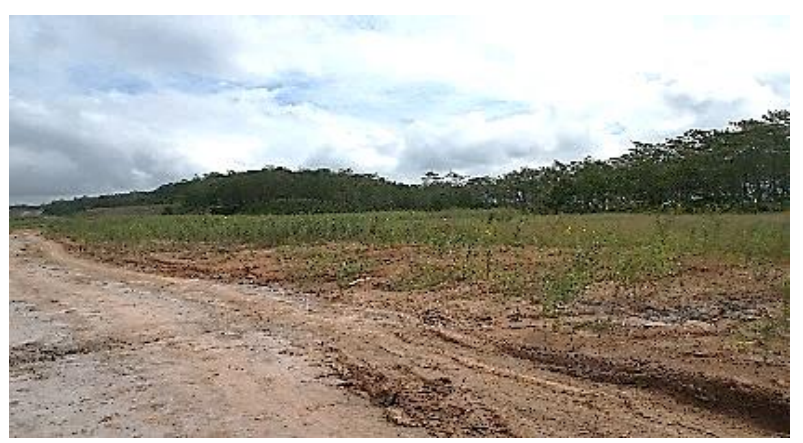

Figure 2 Land preparation at Ex-Pit IPDa-Komodo $2010(5,11 \mathrm{Ha})$

\subsubsection{Land Preparation}

The spacious furnished area was close to the range between $80-89 \%$ of the work plan that has been previously set up (Figure 3). The result of land preparation was found that the realization of the land preparation reached at least $80 \%$ of planned areas, indicating that the landscaping allows the continuation of land revegetation works.

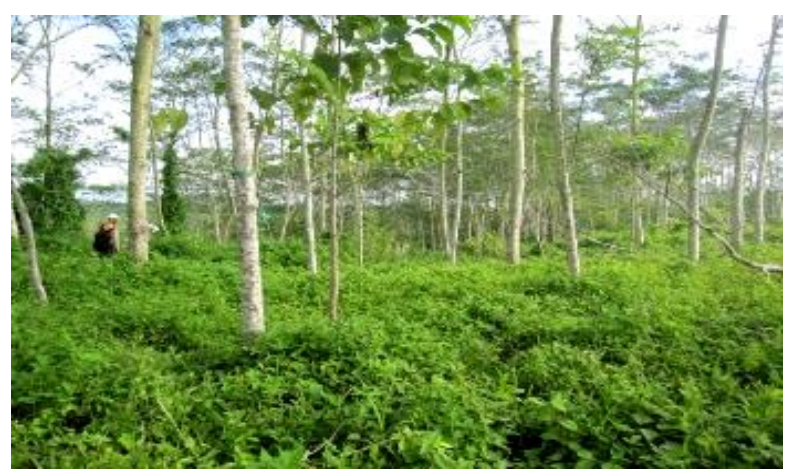

Figure 3 Rehabilitated land after land preparation 


\subsubsection{Slope stability}

Landslides movements were not found and therefore is assessed as very light $(<5 \%)$ in an area of $6.21 \mathrm{ha}$, slightly landslide (5-10\%) in $10.63 \mathrm{ha}$, heavy landslide (15-20\%) in 2.24 ha, as well as a very heavy landslide (>20\%) in 5.39 ha (Figure 4). These facts should be used for similar works in other locations related to slope stability to prevent the occurrence of landslide movements [31].

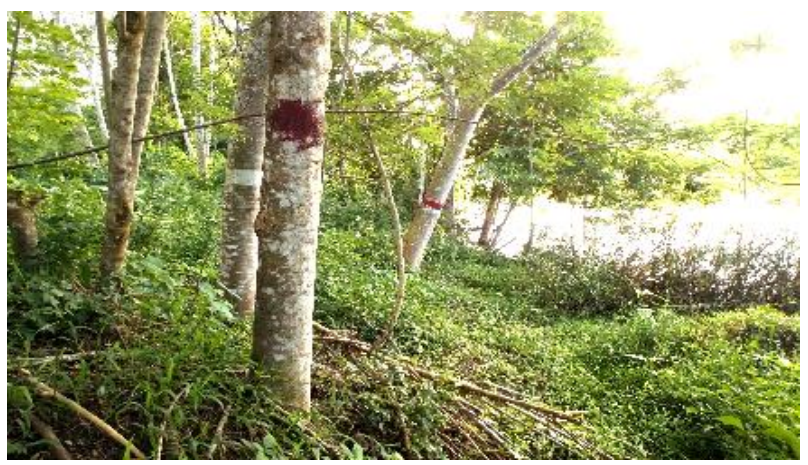

Figure 4 Slope stability at post-mining forest lands

\subsubsection{Topsoils Spreading}

The topsoils spreading was found $>90 \%$ of the plan assigned from a total area of $2.09 \mathrm{ha}, 70-79 \%$ on the site of $2.24 \mathrm{ha}, 60-69 \%$ on the site of $1.10 \mathrm{ha}$, as well as $<60 \%$ on the area of 8.54 ha. The completed topsoils spreading works should be seriously considered an essential reference for similar results at other locations to support plant growth and development of Revegetation works at mined-out forest lands.

\subsection{Soil Erosion and Sedimentation Control}

\subsubsection{Soil Erosion-Sedimentation Control Infrastructure}

The number of soil conservation infrastructures was considered available enough (Figure 5) on the rehabilitated forest land of 24.47 ha (70-79\%) in large. There was also wooden construction of soil conservation infrastructure in the form of a wooden check dam as much as of 2 (two) units (range $80-89 \%$ ) on a reclaimed land area of 1.72 ha (OPDb-M2).

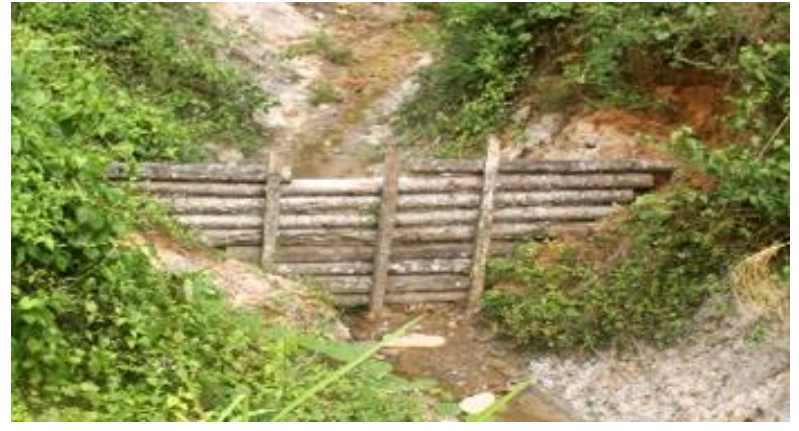

Figure 5 Overland flow control using retarding wooden construction

\subsubsection{Infrastructure Function}

The existing soil conservation infrastructure was considered available and useful related to surface water runoff control efforts and prevention and minimization of soil erosion and sedimentation in the post-mining rehabilitated forest lands. These conditions were found at OPDa-M2 (8.54 ha/2011) and OPDb-M2 (1.72 ha/2010).

\subsubsection{Land Cover Crops}

Cover crops planting was ranging $80-89 \%$, covering $11.36 \mathrm{Ha}$. Cover crops in the early stage of Revegetation are vital to reduce excessive soil erosion and overland flow [2]. It is also expected to increase the organic materials supply into the soil to improve plant nutrients' availability. The condition of planting crops at OPD-Komodo: 5.39 ha/2010) KO-Komodo (2.24 ha/2010) OPDa M2 (8.54 ha/2011) as shown in Figure 6 .

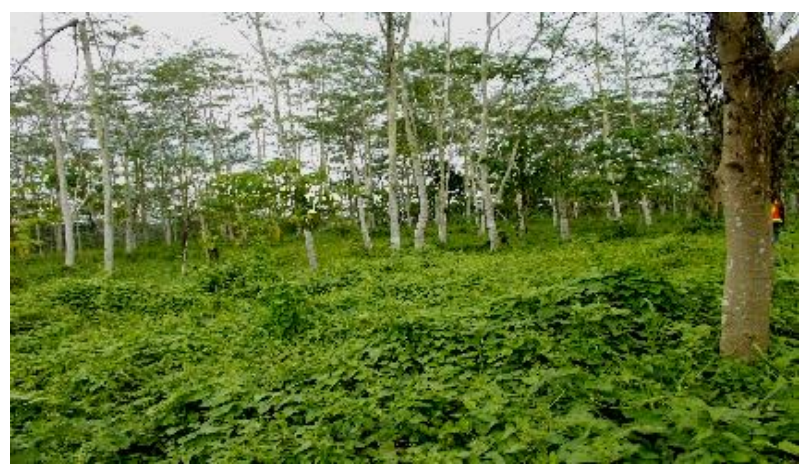

Figure 6 Land cover crops after four years of revegetation works

\subsubsection{Soil Erosion Occurrences}

The soil erosion occurs in the form of rill erosion was found in rehabilitated forest land ranging of 6-10\% in an area with coverage of $5.39 \mathrm{ha}$, whereas the range of $11-15 \%$ at coverage area of 19.08 ha. Is should be noted that these soil occurrences potentially increase to be channel or gully erosion. Therefore, soil erosion 
control measure prevention by adding soil erosion infrastructures must be continuously applied at proper locations.

\subsection{Revegetation}

\subsubsection{Revegetation Area}

Realization of planting works was $>90 \%$ of 21.65 ha area in large, and there was a ranging of $80-89 \%$ in the area of 2.82 ha. Concerning the land surface coverage, as much as $80 \%$ is considered an initial condition to support the recovery process of ecosystem structure and function of post-mining rehabilitated forest lands $[5,9,11]$. The more land surface coverage will invite various wildlife for living and regeneration within rehabilitated forest lands after coal mining operation [3,7] (Figure7).

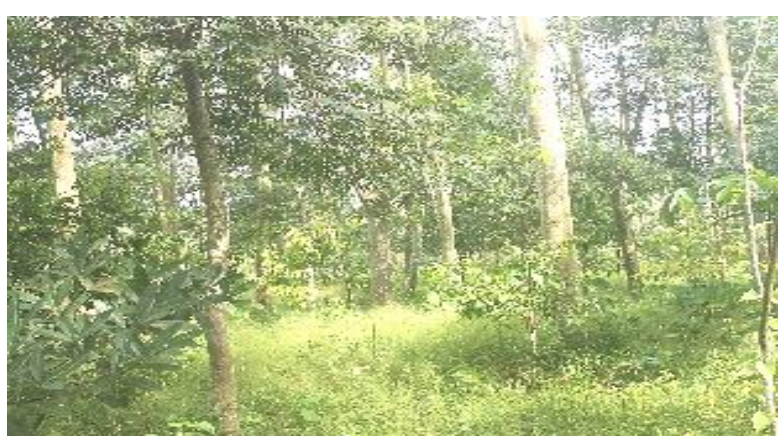

Figure 7 Mixed of fast-growing and long life species after four years

\subsubsection{Growth Percentage}

The growth percentage was $>90 \%$ which is expected to accelerate soil and microclimate recovery for further supporting plant growth. For this reason, plant maintenance is needed to retain its plant growth percentage of which largely determine the growth and development of revegetation plants.

\subsubsection{Planted Plants}

The plant's number was $>625$ plants per hectare in an area of 24,47 ha with a standard planting distance of $4 \mathrm{~m} \times 4 \mathrm{~m}$. It is highly expected that this condition will provide growth space for plant growth, especially longlife plant species. Enclosure land by vegetation canopies with undergrowth reduce rainfall energy collision to the land surface effectively. Thus, the occurrence probability of soil erosion will be minimized and improve the physical soil characteristics and therefore increase infiltration capacity, which will help reduce the occurrence of excessive overland flow.

\subsubsection{Plant Composition}

The composition of longlife local plant species was $>40 \%$ at area of 18,99 ha, $30-39 \%$ of 5,11 ha, and $<10 \%$ at 0,37 ha. This result provides that the composition of local longlife species types reach a minimum composition percentage. Learning from the past, this composition assures that local longlife plant species will survive in line with the recovery of the structure and ecosystem function, leading to ecosystem recovery stages.

\subsubsection{Plant health}

Overall, plants grow healthier with close to percentage $>90 \%$ is a good indication because only healthy plants will be able to survive and become the benchmark of the success of land revegetation at postmining forest land [22,23]. However, it should be supported with the standard management, especially maintenance which is seriously needed to maintain plant health conditions after Revegetation works.

The results assessment of land rehabilitated forest land must be seen in the integrated perspective and not partially related to post-mining forest lands [10]. Therefore, efforts of land arrangement (backfilling, land preparation, slope stability, topsoils spreading), soil erosion and sedimentation control (number of physical infrastructure and extensive benefits, cover crops, soil erosion occurrences), and land revegetation (arranged lands, plant growth percentage, plant species composition, plant health) are a complementary indicator in nature. 
Tabel 3. Evaluation and result of rehabilitated mined-out forest land at IPKKH concession of PT Santan Batubara

\begin{tabular}{|c|c|c|c|c|c|c|c|}
\hline$\frac{\text { Planting block }}{\text { Criteria }}$ & $\begin{array}{c}\text { OPD- } \\
\text { Komodo } \\
\text { (5.39 ha) }\end{array}$ & $\begin{array}{l}\text { IPDa-Komodo } \\
\quad(5.11 \text { ha })\end{array}$ & $\begin{array}{l}\text { KO-Komodo } \\
\text { (2.24 ha) }\end{array}$ & $\begin{array}{c}\text { OPDb-M2 } \\
(1.72 \text { ha })\end{array}$ & $\begin{array}{c}\text { OPDa-M2 } \\
\text { (8.54 ha) }\end{array}$ & $\begin{array}{c}\text { OPDc-M2 } \\
(0.37 \text { ha })\end{array}$ & $\begin{array}{c}\text { OPDd-M2 } \\
(1.10 \text { ha })\end{array}$ \\
\hline 1. Land preparation (20) & 9,33 & 16,00 & 13,33 & 17,33 & 13,33 & 18,67 & 14,67 \\
\hline a. Void backfilling & - & 5 & - & - & - & - & - \\
\hline b. Rehabilitated area & 5 & 5 & 5 & 4 & 5 & 5 & 4 \\
\hline c. Slope sTability & 1 & 5 & 2 & 4 & 4 & 4 & 5 \\
\hline d. Topsoils spreading & 1 & 1 & 3 & 5 & 1 & 5 & 2 \\
\hline $\begin{array}{l}\text { 2. Soil erosion-sediment control } \\
\text { (30) }\end{array}$ & 22,50 & 24,00 & 24,00 & $\mathbf{2 2 , 5 0}$ & $\mathbf{2 2 , 5 0}$ & 24,00 & $\mathbf{2 2 , 5 0}$ \\
\hline a. Infrastucture & 3 & 3 & 3 & 4 & 3 & 3 & 3 \\
\hline b. Function and benefit & 4 & 4 & 4 & 4 & 4 & 4 & 4 \\
\hline c. Land cover crops & 5 & 5 & 5 & 4 & 4 & 5 & 4 \\
\hline d. Soil erosion occurences & 3 & 4 & 4 & 4 & 4 & 4 & 4 \\
\hline 3. Revegetation (50) & $\mathbf{5 0 , 0 0}$ & 48,00 & $\mathbf{5 0 , 0 0}$ & 48,00 & 50,00 & 42,00 & 48,00 \\
\hline a. Planting area & 5 & 5 & 5 & 4 & 5 & 5 & 4 \\
\hline b. Growth percentage & 5 & 5 & 5 & 5 & 5 & 5 & 5 \\
\hline c. Planted plants & 5 & 5 & 5 & 5 & 5 & 5 & 5 \\
\hline d. Plant composition & 5 & 4 & 5 & 5 & 5 & 1 & 5 \\
\hline e. Plant health & 5 & 5 & 5 & 5 & 5 & 5 & 5 \\
\hline Total score & 81,83 & 88,00 & 87,33 & $\mathbf{9 1 , 5 0}$ & 85,83 & 84,67 & 85,17 \\
\hline
\end{tabular}

Tabel 4. Processes, mechanism, and ecosystem recovery indicator within forest ecosystem recovery [3]

\begin{tabular}{llll}
\hline \multicolumn{1}{c}{ Parameter } & \multicolumn{1}{c}{ Until Year-1 } & \multicolumn{1}{c}{ Until Year-2 } & Until Year-3 \\
\hline 1. Avifauna & $\begin{array}{l}\text { Insectivore, many } \\
\text { species }\end{array}$ & $\begin{array}{l}\text { Insectivore/Frugivore/Nectarivore/ } \\
\text { Predator, many species }\end{array}$ & $\begin{array}{l}\text { Insectivore/Frugivore/ } \\
\text { Nectarivore/Predator, the } \\
\text { number of species decreases }\end{array}$ \\
\cline { 2 - 4 } 2. Mammals & Herbivore, fewer species & $\begin{array}{l}\text { Herbivore/Carnivore, the number of } \\
\text { species increasing }\end{array}$ & $\begin{array}{l}\text { Herbivore/Carnivore/ } \\
\text { Omnivore, the number of } \\
\text { species does not change }\end{array}$ \\
\cline { 2 - 4 } $\begin{array}{l}\text { 3. Amphiby } \\
\text { and Reptile }\end{array}$ & $\begin{array}{l}\text { An insectivore, fewer } \\
\text { species }\end{array}$ & $\begin{array}{l}\text { Insectivore/Carnivore, the number } \\
\text { of species increasing }\end{array}$ & $\begin{array}{l}\text { Insectivore/Carnivore, the } \\
\text { number of species does not } \\
\text { change/increasing }\end{array}$ \\
\hline $\begin{array}{l}\text { 4. Butterfly and } \\
\text { dragonfly }\end{array}$ & $\begin{array}{l}\text { Herbivore/Insectivore } \\
\text { many species }\end{array}$ & $\begin{array}{l}\text { Herbivore/Insectivore, the number } \\
\text { of species increasing }\end{array}$ & $\begin{array}{l}\text { Herbivore/Insectivore, the } \\
\text { number of species increasing } \\
\text { change/increasing }\end{array}$ \\
\cline { 2 - 5 } 5. Beetle & Herbivore, fewer species & The number of species increasing & $\begin{array}{l}\text { The number of species } \\
\text { does not change/ } \\
\text { increasing }\end{array}$ \\
\hline
\end{tabular}

The assessment results of rehabilitated minedout forest land is outlined in Table 3. As of the score: OPD Komodo 2010 (5.39 ha) = 81.83; IPDa-Komodo 2010 $(5.11$ ha $)=88.0 ;$ KO-Komodo $2010(2.24$ ha $)=87.3$; OPDb-M2 $2011(1,72$ ha) = 89.3; OPDa-M2 $2010(8.54$ ha) $=85.8$ and OPDc-M2 $2011(0,37$ ha $)=84.7$; OPDdM2 2011 (1.10 ha) =85.2; with total score of 602.1 and 86.0 average. This means that land rehabilitation of minedout forests land can be declared successful $(>80)$.

In a natural ecosystem, the term of food chains is widely known as the relationship between the existence of vegetation as a food producer for the most part planteater (herbivore), while the presence of herbivores is as the provider of food for the meat-eaters (carnivore), a lot of omnivorous and certainly some kind of predator $[3,26,28]$. A lot of food chains will form food webs. The critical question is how much of the food chain and food webs already formed after a heavy forest ecosystem disturbance due to mining operation until it's rehabilitation works? Build a food chain alone is very valuable because of concerns some life. In other words, the land rehabilitation of post-mining forest land already gives the appropriate contribution to support many types of life surrounding. Post mining rehabilitation of forest lands should be viewed together with another natural surrounding forest ecosystem as the benchmark forest ecosystem recovery [10] (Table 4).

The general thinking in the construction of forest land ecosystem recovery after mining operation, the outline of the interaction between the main elements in the ecosystem that concerns the stability of the abiotic component elements (rock/soil, water, air) and energy inputs coming from sunlight will stimulate plant growth. Plants as an independent element (producer) is a source of energy and minerals to consumer (wildlife, micro, meso or macro) [26, 27, 29]. Plants and animals simultaneously contribute to the energy source for the decomposer (micro-organisms), including mesofauna. Interactions complexity between plant-animaldecomposer and inorganic elements (soil, water and air) is often called foodwebs that became an ecological indicator of an ecosystem, both at the climax recovery stage.

The score of ecosystem characteristics involving the formation of re-developing forest ecosystems food webs based on the existence of predator-herbivore-carnivore and still without top predator shows value and status the land rehabilitation of forest land was 70 (3-<6 years age), means that the recovery of ecosystems with 
prospective status (herbivore - predator - carnivore) of recovery level. This ecosystem status indicates that the processes and recovery stage of forest ecosystems has been running in the direction of the expected track, leading to the pre-mining operation's initial condition.

\section{CONCLUSION}

Rehabilitation works with good progress were backfilling of ex-pit mining (>90\%), land preparation $(80 \%)$, soil conservation infrastructures, cover crops coverage $(>80 \%)$, soil erosion occurrence $(<15 \%)$, land revegetation $(>80 \%)$, plant growth percentage $(>90 \%)$, number of plant per-hectare $(>625)$, and plant healthy $(>90 \%)$. Conversely, rehabilitation works that still need improvement were slope stability (very heavy landslide movement $>20 \%)$, topsoils spreading $(<60 \%)$, soil erosion and sedimentation control measures $(<80 \%)$, and land revegetation $(<10 \%)$. The dominant plant species found in rehabilitated forest land are Falcataria mollucana, Gmelina arborea, Cassia siamea, Samanea saman, Accacia auriculiformis, Shorea sp., Euderoxylon zwageri, Neolamarckia cadamba, Alstonia scholaris, Arthocarpus integra, Nephelium lappaceum, Durio zibethinus, Arthocarpus sp., Macaranga tanarius, Duabanga moluccana. Rehabilitated land dominated by fast-growing species plant should be enriched with various longlife plant, especially dipterocarp species, as a critical flagship of tropical rain/humid forest in East Kalimantan.

Based on the setup criteria of the land arrangement after mining operation, soil erosion-sedimentation control measure, as well as land revegetation, the total score granted to PT Santan Batubara of IPPKH 24.47 ha was 86.0 (eighty-six point zero) and can be declared being successful $(>80)$. The score of ecosystem related to foodweb recovery based on incoming herbivores predators - carnivores without top predators was assessed to be 70 (seventy points zero), indicating that the prospective status of ecosystem recovery. The situation shows that the processes and stage of forest ecosystem recovery have been in the expected direction toward pre-mining exploitation.

\section{ACKNOWLEDGMENTS}

Sincere thanks are expressed to PT Santan Batubara for facilitating this study. The authors would also like to acknowledge two other reviewers for critical review of the manuscript.

\section{REFERENCES}

[1] C. Agus, P.B. Putra, E. Faridah, D. Wulandari, R.R.P. Napitupulu, Organic carbon stock and their dynamics in rehabilitation ecosystem areas of post open coal mining at the tropical region. HumTech
2016, 7-9 June 2016, Massachusetts, USA. Procedia Engineering 159. 29-337.

[2] S. Arsyad, Soil and Water Conservation, IPB Press. Bogor, 2006 [in indonesian].

[3] C. Boer, W. Hartati, Sutedjo, T. Sudarmadji, Sukartiningsih, M. Syafrudin, M. Syoim, Ecological recovery dynamics at post mining rehabilitated forest land of PT Berau Coal (2010 2013), 2014 [in Indonesian].

[4] A. Bradshaw, Restoration of mined lands-using natural processes, Journal of Ecological Engineering 8, 1997, pp. 55-269.

[5] R. Lal, B.A. Stewart, Soil Restoration, New York: Springer-Verlag, 1991.

[6] S.D. Bergen, S.M. Bolton, J.L. Fridley, Design principles for ecological engineering, Journal of Ecological Engineering, 18, 2001, pp. 201-210.

[7] E. Charlotte, C.E. Wheeler, P.A. Omeja, C.A. Chapman, M. Glipin, C. Tumwesigye, S.L. Lewis, Carbon sequestration and biodiversity following 18 years of active tropical forest restoration. Forest Ecology and Management 373, 2016, pp. 44-55. Journal www.elsevier.com/locate/foreco.

[8] Y. Chena, D. Li, D. Li, X. Wua, Y Zheng, Assessment for soil improvement benefit of land rehabilitation in dump areas. Mathematical and Computer Modelling 54, 2011, pp. 1204-1212. journal homepage: www.elsevier.com/locate/mcm

[9] Government of Indonesia Act No. 32/2009: Protection and Management of Environment [in Indonesia].

[10] M.R. Guariguatab, J. Rodney, R.J. Keenanc, A proposed framework for assessing ecosystem goods and services from planted forests Himlal Barala, Ecosyetem Services, 2016, J.homepage: www.elsevier.com/locate/ecoser.

[11] R. Haugo, C. Zanger, T. DeMeo, C. Ringo, A. Shlisky, K. Blankenship, M. Simpson, M. MellenMcLean, J. Kertis, M. Stern, A new approach to evaluate forest structure restoration needs across Oregon-Washington, USA, Forest Ecology and Management 335, 2015, pp. 37-50. j.homepage: www.elsevier.com/ locate/foreco

[12] P.C.A.S. Juniora, F.C. Marquesa, M.R. Limab, L. Luiz dos Anjosb, The importance of restoration areas to conserve bird species in a highly fragmented Atlantic forest landscape, Research Letters, 2016. 
[13] A. Kusumandaria, P. Nugroho, Land capability analysis based on hydrology and soil characteristics for watershed rehabilitation, The $5^{\text {th }}$ Sustainable Future for Human Security (SustaiN 2014), Procedia Environmental Sciences 28, 2015, pp. 142-147.

[14] Ministry of Forestry, Decree No. P.76/MenhutII/2008: Forest Rehabilitation and Reclamation [in Indonesian].

[15] Ministry of Forestry, Decree No. P.60/MenhutII/2009: Evaluation of Forest Reclamation [in Indonesian].

[16] Ministry of Forestry, Decree Number P.4/MenhutII/2011: Guidance of Forest Reclamation [in Indonesian].

[17] Ministry of Forestry, Decree No. P.9/MenhutII/2013: Implementation Procedure, Supporting and Incentives of Forest and Land Rehabilitation Activities [in Indonesian].

[18] Ministry of Forestry, Decree No. P.16/MenhutII/2014: Guidance of Forest Tenurial Utilization [in Indonesian].

[19] A. Nunes, G. Oliveira, T. Mexia, A. Valdecantos, Zucca, E.A.C. Costantini, M. Abraham, A. Kyriazopoulos, A. Salah, Prasse, O. Correia, S. Milliken, B. Kotzenj, C. Branquinho. 2016. J.homepage: www.elsevier.com/locate/scitotenv

[20] D. Oktavia, Y. Setiadi, I. Hilwan, The comparison of soil properties in heath forest and post-mined land: basic for ecosystem restoration, The 5th Sustainable Future for Human Security (SustaiN 2014), Procedia Environmental Sciences 28, 2015, pp. 124-131.

[21] Q. Qiuxia Zhang, F. Wang, R. Wang, Research Progress of Ecological Restoration for Wetlands in Coal Mine Areas, 3rd Int'l Conf. on Env. Science and Information Application Technology (ESIAT 2011), Procedia Environmental Sciences 10, 2011, pp. 1933-1938.

[22] H. Ren, L. Yang, N. Liu, Review Nurse plant theory and its application in ecological restoration in lower subtropics of China, Progress in Natural Science 18, 2008, pp. 137-142.

[23] A.S. Shan, F. Darboux, M. Cheng, Revegetation as an efficient means of increasing soil aggregate stability on the Loess Plateau (China). Geoderma 209-210, 2013, pp. 75-85. J.homepage: www.elsevier.com/ locate/ geoderma.

[24] F.S. Shana, C. Jianga, Y. Boa, D.Z. Shub, Re-use strategy of subsided land based on urban space ecological compensation: case study for Xuzhou mining area, The 6th International Conference on Mining Science and Technology, Procedia Earth and Planetary Science 1, 2009, pp. 982-988.

[25] K.D. Shepherd, G. Shepherd, M.G. Walsh, Land health surveillance and response: A framework for evidence-informed land management, Agricultural Systems 132, 2015, pp. 93-106. Agricultural Systems journal homepage: www.elsevier.com/locate/agsy.

[26] S. Surya, Landscape Ecological Urbanism for Restoration of Pallikaranai Marsh Land, Chennai, Tamil Nadu.International Conference on Emerging Trends in Engineering, Science and Technology (ICETEST), 2016.

[27] T.M. Fayle, E.C. Turner, Y. Basset, R.M. Ewers, G. Reynolds, V. Novotny, Whole-ecosystem experimental manipulations of tropical forests Lessons Learned from Bison Restoration Efforts in Utahi on Western Rangelands By Bill Bates and Kent Hersey, 2013.

[28] K.B. Wasson, A. Suarez, A.E.J. McCarthy, K.S. Kildowc, M. Johnson, C.A. Fountain, M. Woolfolk, Silberstein, P.L.D. Feliz, Marine Policy Lessons learned from an ecosystem-based management approach to restoration of a California estuary. Marine Policy, 58, 2015, pp. 60-70. www.elsevier.com/ locate/marpol

[29] Z. Zhiguo, S. Naiqi, W. Yingshua, L. Yongcheng, S. Yanyan, H. Tao, Geo. Environment Problems and Countermeasures of Shijiaying Mine in Western Beijing, Procedia Environmental Sciences 10, 2011, pp. 1933-1938.

[30] M. Zou, K. Zhu, J. Yin, B. Gu, Analysis on Slope Revegetation Diversity in Different Habitats, Int'l Conf. on Structural Computation and Geotechnical Mechanics, Procedia Earth and Planetary Science 5, 2012, pp. 180-187. 